\title{
Cadmium Accumulation by a Citrobacter sp.: the Chemical Nature of the Accumulated Metal Precipitate and its Location on the Bacterial Cells
}

\author{
By LYNNE E. MACASKIE, ${ }^{\dagger} \dagger$ ALASTAIR C. R. DEAN, ${ }^{*}$ \\ ANTHONY K. CHEETHAM, ${ }^{2}$ ROGER J. B. JAKEMAN ${ }^{2}$ \\ AND A. JEROME SKARNULIS ${ }^{2}$ \\ ${ }^{1}$ Physical Chemistry Laboratory, University of Oxford, South Parks Road, \\ Oxford $O X 13 Q Z, U K$ \\ ${ }^{2}$ Laboratory of Chemical Crystallography, University of Oxford, Parks Road, \\ Oxford $O X 13 P D, U K$
}

(Received 18 July 1986; revised 30 September 1986)

Cells of a strain of a Citrobacter sp., pre-grown in cadmium-free continuous culture, accumulated cadmium extensively when resuspended in a buffer that contained $\mathrm{Cd}^{2+}$ and glycerol 2phosphate. The accumulated compound was identified by $\mathrm{X}$-ray microanalysis and magic angle spinning NMR analysis as cell-bound cadmium phosphate, probably $\mathrm{CdHPO}_{4}$. Its accumulation is consistent with the activity of a phosphatase, induced during pre-growth, that continues to function in the resuspended cells to liberate $\mathrm{HPO}_{4}^{2-}$ from glycerol 2-phosphate. This anion then combines with $\mathrm{Cd}^{2+}$ to form insoluble cell-bound $\mathrm{CdHPO}_{4}$.

\section{INTRODUCTION}

A strain of a species of Citrobacter, originally isolated from metal-polluted soil (Macaskie \& Dean, 1982), was tolerant to cadmium, and accumulated the metal when grown in its presence (Macaskie \& Dean, 1982, 1984a). The potential to accumulate $\mathrm{Cd}^{2+}$ was present also in cells pregrown in the absence of the metal and was retained in cells subsequently challenged with $\mathrm{Cd}^{2+}$ in the resuspended ('resting') and immobilized states (Macaskie \& Dean, 1984a,b); this property formed the basis for a biological process designed for the removal of heavy metal cations from liquid industrial wastes (Macaskie \& Dean 1984b, c, 1985a,b; Michel et al., 1986; Macaskie et al., 1987).

The time-dependent accumulation of cadmium (Macaskie \& Dean, 1984a), together with a requirement for glycerol 2-phosphate (Macaskie \& Dean, 1984a) or other suitable organic phosphate (Michel et al., 1986) present in the perfusing cadmium-containing solution, suggested an enzymically mediated metal uptake mechanism, possibly involving an acid-phosphatasetype enzyme cleaving the organic phosphate to yield $\mathrm{HPO}_{4}^{2-}$ (Kawabe et al., 1981); indeed, quantitative conversion of glycerol 2-phosphate to inorganic phosphate by Citrobacter cells that have not been exposed to metals has been observed (Macaskie et al., 1987). The inorganic phosphate released would then precipitate with $\mathrm{Cd}^{2+}$ to form insoluble cadmium phosphate; a kinetic interpretation of the release of inorganic phosphate and the accumulation of cadmium by immobilized cells supports a reaction mechanism of this type in this Citrobacter sp. (Macaskie et al., 1987), while previous studies on the uptake of lead by a different strain of Citrobacter (see below) suggested that the lead was accumulated as $\mathrm{PbHPO}_{4}$ (Aickin et al., 1979).

In contrast to the evidence for the role of phosphatase in metal accumulation, direct evidence for the production of cell-bound cadmium phosphate has been hitherto lacking; information on

$\dagger$ Present address: Microbiology Unit, Department of Biochemistry, University of Oxford, South Parks Road, Oxford OXI 3QU, UK.

Abbreviation: MASNMR, magic angle spinning nuclear magnetic resonance. 
the chemical nature of the presumptive cadmium phosphate precipitate would be particularly useful in establishing whether this Citrobacter sp. behaves as predicted from the studies of Kawabe et al. (1981) and Aickin et al. (1979) as described above. This study provides the first photographic documentation of the accumulation of cadmium by this Citrobacter sp., and simultaneous analytical studies have permitted identification of the chemical nature of the cadmium precipitate on the cells.

\section{METHODS}

Organism. The Citrobacter sp. was described by Macaskie \& Dean $(1982,1984 a)$. This strain was separate and distinct from the Citrobacter sp. reported to accumulate lead by Aickin \& Dean, $(1977,1979)$, differing in colony morphology, growth temperatures and responses to nine standard biochemical tests (reports from the National Collection of Industrial Bacteria, Torry Research Station, Aberdeen, UK : report no. TRS/141/3/398, 1978, and no. TRS/141/3/579, 1981). Additionally, the lead-accumulating Citrobacter sp. accumulated little cadmium (R. M. Aickin, L. E. Macaskie \& A. C. R. Dean, unpublished), while the Citrobacter sp. used in this study was metal nonspecific (Macaskie \& Dean, 1984c, 1985a, b).

Growth of the organism. The Citrobacter sp. was grown in carbon-limiting continuous culture in a medium having the following composition ( $\left.\mathrm{g} \mathrm{l}^{-1}\right)$ : Tris, $12.0 ;\left(\mathrm{NH}_{4}\right)_{2} \mathrm{SO}_{4}, 0.96$; glycerol 2-phosphate. $5 \cdot 5 \mathrm{H}_{2} \mathrm{O}(\mathrm{BDH}), 0.67 ; \mathrm{KCl}$, $0.62 ; \mathrm{MgSO}_{4} .7 \mathrm{H}_{2} \mathrm{O}, 0.063 ; \mathrm{FeSO}_{4} .7 \mathrm{H}_{2} \mathrm{O}, 0.00032$; glycerol, 0.6 , with the $\mathrm{pH}$ adjusted to 7.0 with $2 \mathrm{M}-\mathrm{HCl}$. Polypropylene glycol antifoam was incorporated at $1 \mathrm{ml}$ per 101 of medium. The cultures were maintained at $30^{\circ} \mathrm{C}$ in a New Brunswick 'Bioflo' apparatus (agitation 400 r.p.m.; air flow 0.5 litres $\mathrm{min}^{-1}$ ) at $D=0.26 \mathrm{~h}^{-1}$ $\left(0.5 \mu_{\text {max }}\right)$. Steady-state was attained after 24 generations of growth $(3 \mathrm{~d})$ after which the outflow culture was harvested. The bacterial dry wt of the culture $\left(\mu \mathrm{g} \mathrm{ml}^{-1}\right)$ was determined turbidimetrically using a Hilger Spekker photoelectric absorptiometer and the turbidity readings were related to dry wt using a calibration plot. Dry wts were determined by harvesting the organisms by centrifugation $\left(5000 \mathrm{~g} ; 15 \mathrm{~min} ; 4^{\circ} \mathrm{C}\right)$, washing the bacterial pellet once with the same volume of distilled water and then drying it to constant weight at $105^{\circ} \mathrm{C}$.

Cadmium uptake by resting cells. The culture outflow $\left(240 \mu \mathrm{g}\right.$ dry $\left.\mathrm{wt} \mathrm{m}^{-1}\right)$ was harvested by centrifugation, washed once with isotonic saline $\left(8.5 \mathrm{~g} \mathrm{NaCl}^{-1}\right)$ and resuspended to $120 \mu \mathrm{g}$ dry wt $\mathrm{ml}^{-1}$ in $100 \mathrm{~mm}-\mathrm{Tris} / \mathrm{HCl}$ buffer (pH 7.0) supplemented with $2 \mathrm{mM}$-glycerol 2-phosphate and cadmium sulphate $\left(3 \mathrm{CdSO}_{4} .8 \mathrm{H}_{2} \mathrm{O} ; \mathrm{BDH}\right)$ as required (resuspension medium). The final $\mathrm{pH}$ was adjusted to $7 \cdot 0$. The suspensions were incubated with agitation at $20^{\circ} \mathrm{C}$ and samples withdrawn at intervals. These were harvested $(4 \mathrm{mg}$ dry wt) washed in distilled water and dried to constant weight at $105^{\circ} \mathrm{C}$. The pellets were then heated at $280^{\circ} \mathrm{C}$ with a mixture of concentrated nitric and sulphuric acids $(1: 1, \mathrm{v} / \mathrm{v})$ until a clear solution was obtained. The acid digests were neutralized with $2 \mathrm{M}-\mathrm{KOH}$ against phenolphthalein, diluted to $100 \mathrm{ml}$ with distilled water and assayed for their cadmium contents by anodic stripping voltammetry (Aickin \& Dean, 1977).

Electron microscopy. Samples of cells loaded with cadmium were withdrawn from the resuspension medium as required, and washed once with isotonic saline and once with distilled water. The pellets were resuspended in distilled water to make a concentrated suspension. One drop was placed on a copper electron microscope grid that had been pre-coated with a carbon film (about $2 \mathrm{~nm}$ thick) (Baumeister \& Seredynski, 1976) and air-dried overnight. The grids were loaded into a JEM-2000FX electron microscope (Jeol), and examined in the scanning transmission electron microscopy (STEM) mode with an accelerating voltage of $200 \mathrm{keV}$.

$X$-Ray microanalysis of the accumulated cadmium precipitate. The cell preparations were analysed using the JEM$2000 \mathrm{FX}$ instrument in conjunction with an energy dispersive X-ray spectrometer (Tracor) which allowed elementary analysis of specimen microareas (approximately $1 \mu \mathrm{m}^{2}$ in the STEM mode). X-Ray spectra were accumulated for $100 \mathrm{~s}$ and data analyses were done using a Tracor TN-5500 system. Comparisons were done with samples of pure $\mathrm{Cd}_{3}\left(\mathrm{PO}_{4}\right)_{2}$ and $\mathrm{Cd}_{2} \mathrm{P}_{2} \mathrm{O}_{7}$, prepared by solid state reaction and checked for purity by $\mathrm{X}$-ray powder diffraction.

Magic angle spinning NMR (MASNMR) analyses of the cadmium-loaded cells. Cadmium-free or cadmium-loaded resuspensions $\left(3 \mathrm{l} ; 200 \mu \mathrm{g} \mathrm{Cd}^{2+} \mathrm{ml}^{-1}\right.$; exposure time $3 \mathrm{~h}$ ) were harvested and washed as described above. The samples were dried at $105^{\circ} \mathrm{C}$ and ground to a powder. Magic angle spinning was done on a Bruker CXP200 instrument with samples loaded in Delrin Andrews-type rotors and spun at about $3.5 \mathrm{kHz}$. Typically, 200 transients were collected by using a $5 \mu$ s pulse and a recycle delay of $10 \mathrm{~s}$. Chemical shifts are given in p.p.m. with respect to an external standard of $85 \% \mathrm{H}_{3} \mathrm{PO}_{4}$ with upfield taken as negative.

\section{RESULTS}

Cadmium accumulation by resting cells of Citrobacter sp.

Preliminary experiments assessed the capacity of resuspended 'resting' cells to accumulate cadmium. We reported previously that batch pre-grown cells accumulated cadmium to $40 \%$ of 
the bacterial dry wt after exposure to $1000 \mu \mathrm{g} \mathrm{Cd}^{2+} \mathrm{ml}^{-1}$ for $18 \mathrm{~h}$ (Macaskie \& Dean, 1984b). By contrast, resting cells pre-grown in glycerol-limiting continuous cultures accumulated similar amounts of cadmium after only $5 \mathrm{~h}$ when exposed to $200 \mu \mathrm{g} \mathrm{Cd}^{2+} \mathrm{ml}^{-1}$, reflecting the superiority of the present pre-growth technique. The rates and extents of cadmium accumulation were dependent on the concentration of $\mathrm{Cd}^{2+}$ presented to the cells. At high cadmium concentrations $\left(500 \mu \mathrm{g} \mathrm{ml}^{-1}\right)$ after extended exposures $(24 \mathrm{~h})$, the apparent uptake of $\mathrm{Cd}^{2+}$ was in excess of $100 \%$ of the bacterial dry wt, and it is likely that precipitated cadmium was deposited also in the medium. To avoid obscuring the bacterial cells, $200 \mu \mathrm{g} \mathrm{Cd}^{2+} \mathrm{ml}^{-1}$ was chosen as a convenient concentration, and samples withdrawn at up to $5 \mathrm{~h}$ from the resuspensions provided cadmium loadings suitable for microscopical analysis. The cadmium loading of each bacterial sample examined was confirmed as described in Methods. Control experiments without bacteria established that no spontaneous precipitation of cadmium occurred. No bacterial growth occurred in cell-supplemented resuspensions both due to the generalized toxicity of the cadmium concentrations used and to the lack of a metabolizable nitrogen source.

\section{Microscopic examination}

Samples withdrawn at intervals during resuspension in cadmium-containing $\left(200 \mu \mathrm{g} \mathrm{ml}^{-1}\right)$ medium were examined under the electron microscope as described, without fixing or staining of the preparation in any way. Cells withdrawn before exposure to cadmium or during cadmiumfree resuspension were poorly represented photographically (Fig. 1a) as might be expected. However, in cells withdrawn after $3 \mathrm{~h}$ exposure to cadmium (which had accumulated the metal to $27 \%$ of bacterial dry wt), the loaded metal was visible as an electron-opaque stain giving an overall darkened appearance with loci of heavier precipitate, also extruded into areas immediately surrounding the cells (Fig. $1 b$ ). This differs from previous observations on the uptake of lead by another Citrobacter sp.: in the latter case the metal was retained upon the cells (Aickin et al., 1979), although it should be noted that in molar terms the cadmium accumulated in the present case exceeded that reported for lead by about $50 \%$. After further exposure to cadmium $(5 \mathrm{~h})$ the cadmium content of the cells was $40-45 \%$ of the bacterial dry wt and the damage imposed by this burden resulted in a loss in cell integrity in the electron beam under high vacuum. Visible cell disruption occurred with extrusion of bound material (Fig. 1c), while in other cases the cells disintegrated completely to leave 'ghost' imprints of precipitated cadmium (Fig. 1d).

\section{$X$-Ray microanalysis of the accumulated cadmium}

Cells were withdrawn at intervals from the resuspension medium and the progress of cadmium accumulation was followed retrospectively by X-ray microanalysis of the dried cells. The X-ray spectra emitted from the specimens (Fig. 2) indicated a parallel accumulation of both cadmium and phosphorus by the cells (Fig. $2 b, c$ ), while cells grown without cadmium had only a low level of phosphorus associated with biological material, and no accumulated metal (Fig. 2a). The peaks observed for copper were due to its presence in the grid. Quantitative data as to absolute amounts of cadmium and phosphorus present could not be determined by this technique, but the data can be interpreted by the ratio method to give the relative amounts of each element. For thin specimens the effects of absorption and fluorescence encountered in bulk samples are negligible and the relative concentrations of elements are related to their X-ray emission intensities by the equation

$$
X_{1} / X_{2}=\mathrm{k} I_{1} / I_{2}
$$

where $\mathrm{k}$ is a constant and $X_{1}, X_{2}, I_{1}$ and $I_{2}$ represent, respectively, the concentrations and the emission intensities of the two elements (Cliff \& Lorimer, 1975). Thus, from the relative cadmium and phosphorus peak areas obtained from the $\mathrm{X}$-ray emission spectra a $\mathrm{Cd}: \mathrm{P}$ ratio can be obtained which can be compared with that obtained using pure chemical compounds of known molar ratio of $\mathrm{Cd}: \mathrm{P}$. Pure $\mathrm{Cd}_{3}\left(\mathrm{PO}_{4}\right)_{2}$ (molar ratio $\mathrm{Cd}: \mathrm{P}=3: 2$ ) gave a value for $I(\mathrm{Cd} L) / I(\mathrm{PK})$ of $2.510 \pm 0.066$ (mean $\pm \mathrm{SEM}$, nine samples) in the above equation, whereas the corresponding value for $\mathrm{Cd}_{2} \mathrm{P}_{2} \mathrm{O}_{7}$ (molar ratio $\left.\mathrm{Cd}: \mathrm{P}=1: 1\right)$ was $1.864 \pm 0.054$ (mean $\pm \mathrm{SEM}$, 

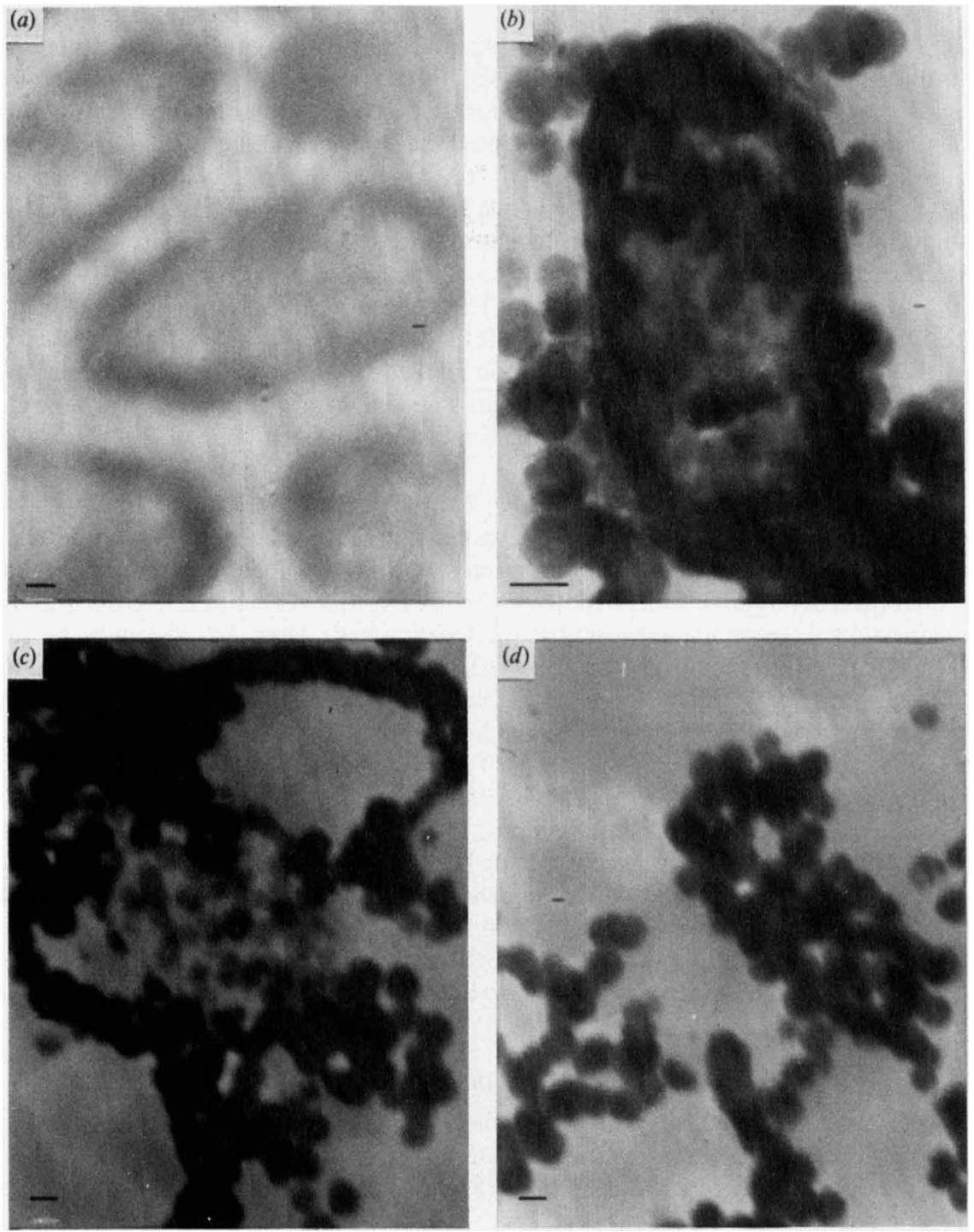

Fig. 1. Accumulation of cadmium by resting cells. Samples were withdrawn during progressive cadmium accumulation (exposure concentration $200 \mu \mathrm{g} \mathrm{Cd}^{2+} \mathrm{ml}^{-1}$ ) and examined, dried but unstained, in the electron microscope. (a) Cells withdrawn before exposure to cadmium or during resuspension in cadmium-free media; $(b)$ cadmium loading of $27 \% ;(c, d)$ cadmium loading of $45 \%$ of bacterial dry wt. Bars, $100 \mathrm{~nm}$.

ten samples). Similar analysis of the X-ray spectra of cadmium-loaded cells gave a value of 1.925 $\pm 0 \cdot 110$ (mean $\pm \mathrm{SEM}$, four independent cell preparations), which was not significantly different from the value obtained using $\mathrm{Cd}_{2} \mathrm{P}_{2} \mathrm{O}_{7}$, i.e. the molar ratio of $\mathrm{Cd}: \mathrm{P}$ on the cells was $1: 1$.

Nature of the cadmium phosphate precipitate on the cells

It should be emphasized that the above data do not show the accumulated cadmium phosphate to be $\mathrm{Cd}_{2} \mathrm{P}_{2} \mathrm{O}_{7}$, but merely that cadmium and phosphorus were accumulated in a $1: 1$ molar ratio, a criterion equally applicable to $\mathrm{CdHPO}_{4}$. In contrast to lead (Aickin et al., 1979), samples of pure $\mathrm{CdHPO}_{4}$ were not obtainable and the use of this compound as a direct comparison with the cadmium-loaded cells was precluded. However confirmation that the 


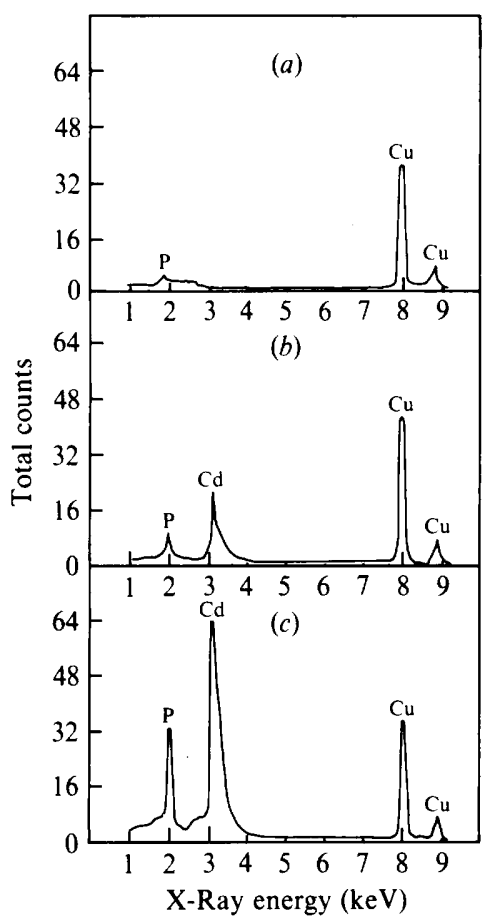

Fig. 2

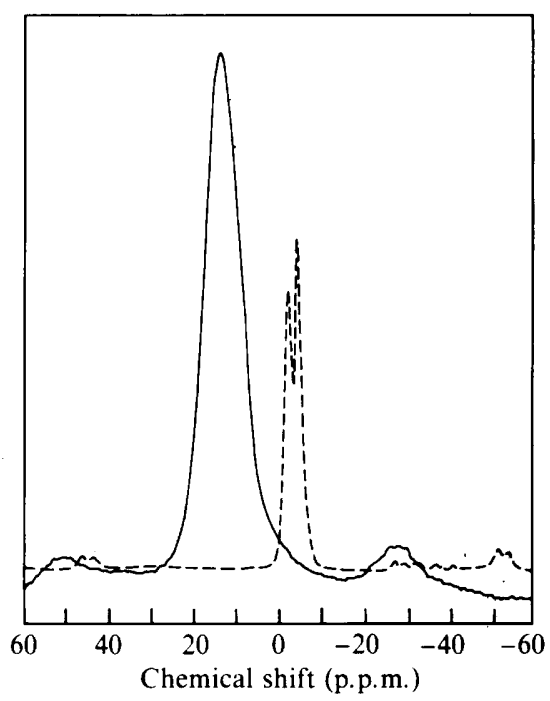

Fig. 3

Fig. 2. X-Ray spectra of Citrobacter sp. withdrawn during progressive cadmium uptake. Details as in Fig. 1 legend. The spectra represent analysis of small areas of individual cells. (a) Cells withdrawn before exposure to cadmium; $(b) 2 \mathrm{~h}$ exposure (cadmium loading $18 \%$ of bacterial dry wt); $(c) 3 \mathrm{~h}$ exposure (cadmium loading $27 \%$ of bacterial dry wt), corresponding to the cell shown in Fig. $1 b$.

Fig. 3. ${ }^{31}$ P MASNMR spectra (see Methods) of cadmium-loaded cells $(-)$ and of pure $\mathrm{Cd}_{2} \mathrm{P}_{2} \mathrm{O}_{7}$ (----). The Citrobacter sample used corresponds to the samples shown in Figs $1(b)$ and $2(c)$ (cadmium loading $27 \%$ of bacterial dry wt). The chemical shifts are given relative to an external standard of $85 \%$ $\mathrm{H}_{3} \mathrm{PO}_{4}$ with upfield taken as negative.

accumulated compound was not $\mathrm{Cd}_{2} \mathrm{P}_{2} \mathrm{O}_{7}$ was obtained by NMR analysis (Fig. 3). The ${ }^{31} \mathrm{P}$ MASNMR spectra of pure $\mathrm{Cd}_{2} \mathrm{P}_{2} \mathrm{O}_{7}$ and finely ground cadmium-loaded cells (Fig. 3 ) show that they resonate at significantly different chemical shifts, and so can be readily distinguished. Moreover, the resonance of the cadmium-loaded cells is in the region expected for a cadmium orthophosphate, such as $\mathrm{CdHPO}_{4}$, i.e. downfield of the pyrophosphate $\mathrm{Cd}_{2} \mathrm{P}_{2} \mathrm{O}_{7}$ (Cheetham et al., 1986). No phosphorus resonances were detected from cells that had not been exposed to cadmium.

\section{DISCUSSION}

This study clearly establishes that cadmium is accumulated as the metal phosphate at the cell surface. Although it is not possible to prove conclusively that the compound accumulated was $\mathrm{CdHPO}_{4}$, the evidence for this is strong since cadmium and phosphorus were shown to be accumulated in a molar ratio of $1: 1$, in agreement with kinetic data (Macaskie et al., 1987) and with results previously reported for the accumulation of lead as $\mathrm{PbHPO}_{4}$ (Aickin et al., 1979). NMR analysis has shown $\mathrm{HPO}_{4}^{2-}$ to be liberated during phosphatase-mediated cleavage of organic phosphate (Kawabe et al., 1981), while various other lines of evidence support the involvement of phosphatase in cadmium uptake. The upper $\mathrm{pH}$ limit for both phosphatase activity and metal accumulation is $9 \cdot 25$ (see Macaskie \& Dean, 1985b), while cadmium uptake is 
sensitive to fluoride (Macaskie \& Dean, 1984a), a diagnostic feature of 'acid' phosphatases (Torriani, 1960; Bolton \& Dean, 1972).

The observation that cadmium is bound both as a general, overall, electron-dense stain and also as loci of intense electron-opacity (Fig. $1 \mathrm{~b}$ ) probably reflects two types of uptake: 'passive' uptake due to generalized binding of metal cations to cell-surface components (Baldry \& Dean, 1980) and enzymically mediated, glycerol-2-phosphate-dependent precipitation as cell-bound $\mathrm{CdHPO}_{4}$. Cytochemical studies in Escherichia coli have suggested phosphatase to be located at or near the cell surface (Wetzel et al., 1970), and the finding that neither phosphatase activity (H. Griffiths, S. Hambling \& A. C. R. Dean, unpublished) nor cadmium uptake (Macaskie \& Dean, $1984 a$ ) were increased by disrupting the cells suggested that no permeability barrier existed to either glycerol 2-phosphate or cadmium. The observation that heavy cadmium precipitation occurred at discrete loci at the cell surface provides further corroborative evidence for the surface location of the phosphatase; investigations into this aspect of the enzyme are continuing.

The authors wish to acknowledge the excellent technical assistance of Mrs A. Stoker. They are also indebted to the Science and Engineering Research Council for the provision of a grant (no. GR/C/84088) towards the purchase of the electron microscope for A. K. C. and for financial support to R. J. B. J.

\section{REFERENCES}

AICKIN, R. M. \& DEAN, A. C. R. (1977). Lead accumulation by micro-organisms. Microbios Letters 5, 129-133.

AICKIN, R. M. \& DEAN, A. C. R. (1979), Lead accumulation by Pseudomonas fluorescens and by a Citrobacter sp. Microbios Letters 9, 55-66.

Aickin, R. M., Dean, A. C. R., Cheetham, A. K. \& SKaRNULIS, A. J. (1979). Electron microscope studies on the uptake of lead by a Citrobacter sp. Microbios Letters 9, 7-15.

BaldRY, M. G. C. \& Dean, A. C. R. (1980). Copper accumulation by Escherichia coli strain FE 12/5.2. Uptake by resting organisms. Microbios Letters 15, 105-111.

Baumeister, W. \& Seredynski, J. (1976). Preparation of perforated films with predetermined hole size distribution. Micron 7, 49-54.

Bolton, P. G. \& DeAN, A. C. R. (1972). Phosphatase synthesis in Klebsiella (Aerobacter) aerogens growing in continuous culture. Biochemical Journal 127, 8796.

Cheetham, A. K., Clayden, N. J., Dobson, C. M. \& JAKEMAN, R. J. B. (1986). Correlations between ${ }^{31}$ P N.M.R. chemical shifts and structural parameters in crystalline inorganic phosphates. Journal of the Chemical Society 195-197.

ClifF, G. \& LoRIMER, G. W. (1975). The quantitative analysis of thin specimens. Journal of Microscopy 103, 203-207.

Kawabe, H., Sugiura, Y. \& TANake, H. (1981). ${ }^{31} \mathrm{P}$ and ${ }^{17} \mathrm{O}$ NMR of $\mathrm{Mn}(\mathrm{III})$-containing acid phosphatase. Biochemical and Biophysical Research Communications 103, 327-331.

Macaskie, L. E. \& Dean, A. C. R. (1982). Cadmium accumulation by micro-organisms. Environmental Technology Letters 3, 49-56.

MACASKIE, L. E. \& DEAN, A. C. R. (1984a). Cadmium accumulation by a Citrobacter sp. Journal of General Microbiology 130, 53-62.

MaCaskie, L. E. \& Dean, A. C. R. (1984b). Cadmium accumulation by immobilized cells of a Citrobacter sp. Environmental Technology Letters 5, 177-186.

Macaskie, L. E. \& Dean, A. C. R. (1984c). Heavy metal accumulation by immobilized cells of a Citrobacter sp. Biotechnology Letters 6, 71-76.

MACASKIE, L. E. \& DeAN, A. C. R. (1985a). Uranium accumulation by immobilized cells of a Citrobacter sp. Biotechnology Letters 7, 457-462.

MACASKIE, L. E. \& DeAN, A. C. R. (1985b). Strontium accumulation by immobilized cells of a Citrobacter sp. Biotechnology Letters 7, 627-630.

Macaskie, L. E., Wates, J. M. \& Dean, A. C. R. (1987). Cadmium accumulation by a Citrobacter sp. immobilized on gel and solid supports : applicability to the treatment of wastes containing heavy metal cations. Biotechnology and Bioengineering (in the Press).

Michel, L. J., Macaskie, L. E. \& Dean, A. C. R. (1986). Cadmium accumulation by immobilized cells of a Citrobacter sp. using various phosphate donors. Biotechnology and Bioengineering 28, 1358-1365.

TORRIANI, A. (1960). Influence of inorganic phosphate in the formation of phosphatases by Escherichia coli. Biochimica et biophysica acta 38, 460-479.

Wetzel, B. K., SPICER, S. S., Dvorak, H. F. \& HePpel, L. A. (1970). Cytochemical localization of certain phosphatases in Escherichia coli. Journal of Bacteriology 104, 529-542. 